\title{
Characteristics of Brown Rive var. Inpari 43 and Sonication Treatments for Extraction of Phenolic and Flavonoid Contents
}

\author{
Hadi Munarko ${ }^{1,2}$, Slamet Budijanto ${ }^{3,4 *}$, Azis Boing Sitanggang3,4, Feri Kusnandar ${ }^{3,4}$ \\ ${ }^{1}$ Department of food technology, Faculty of Engineering, Universitas Pembangunan Nasional \\ "Veteran" Surabaya, East Java, Indonesia \\ ${ }^{2}$ Graduate Student of Food Science, Department of Food Science and Technology, IPB University, Bogor, \\ Indonesia \\ ${ }^{3}$ Department of Food Science and Technology, Faculty of Agricultural Engineering, IPB University, Bogor, \\ Indonesia \\ ${ }^{4}$ Southeast Asian Food and Agricultural Science and Technology (SEAFAST) Center, IPB University, Bogor, \\ Indonesia
}

*Corresponding author:

E-mail:

slamet.budijanto@gmail.com

\begin{abstract}
This study aimed to characterize brown rice grain var. Inpari 43 and evaluate the effect of sonication extraction on total phenolic and flavonoid content. The result showed that Inpari 43 is classified as medium and slender grain which contains about $12 \%$ of moisture content. Sonication method was suitable for brown rice flour extraction. It accumulated 65-70 mg GAE/100g and 13-18 mg QE/100g of total phenolic content and flavonoid content, respectively, during 10 to 30 minutes extraction. The pearson correlation analysis indicated a strong positive correlation between extraction time and phenolic and flavonoid content. In conclusion, sonication for 30 minutes accumulates the highest phenolic and flavonoid content in brown rice flour var. Inpari 43.

Keywords: Brown rice, sonication, rice grain, total flavonoid, total phenolic content
\end{abstract}

\section{Introduction}

As a source of carbohydrate in half of the world population, rice is an important commodity and is one of the leading cereal grain in the world. Rice is considered as the major staple food in Asia, especially in Indonesia. Due to the statistics data, the consumption of rice in Indonesia within 2017 reached $111.58 \mathrm{~kg}$ per capita per year (Statistics Indonesia, 2019). In recent decades, consumption of brown rice or unpolished rice has become a good choice because it is more nutritious and contains rich bioactive compounds with numerous health benefits. One of the primary bioactive compounds in brown rice is phenolic compounds (Munarko et al., 2020; Qiu, Liu, \& Beta, 2010).

Phenolic compounds are secondary metabolites commonly distributed in the plant kingdom. The extraction process from plant matrix, including in brown rice, is a crucial step to increase the yield of targetted compounds. Moreover, it can provide a robust and reproducible extraction method which is independent of the variation of the plant raw materials (Monton \& Luprasong, 2019). Sonication refers to the process of extraction that apply sound energy to mix and agitate a liquid containing particles.

Inpari 43 is one of the potential high-yield variety that has been developed by Indonesian Center for Rice Research. It has low amylose content and suitable cultivated in the lowland irrigation area. Our previous research showed that brown rice var. Inpari 43 had a number of bioactive compounds and antioxidant activity (Munarko et al., 2020).

\section{How to cite:}

Munarko, H., Budijanto, S., Sitanggang, A. B., \& Kusnandar, F. (2020). Characteristics of brown rice var. inpari 43 and sonication treatments for extraction of phenolic and flavonoid contents. $1^{\text {st }}$ International Conference Eco- Innovation in Science, Engineering, and Technology. NST Proceedings. pages 52-56. doi: 10.11594/ nstp.2020.0507 
However, there was a lack of information on brown rice var. Inpari 43 characteristics and accumulation of phenolic and flavonoid content at different extraction time by using sonication method. Thus, the aim of this research was to characterize brown rice var. Inpari 43 and to investigate the effect of extraction time on the total phenolic and flavonoid content.

\section{Research Methods}

\section{Materials}

Paddy var. Inpari 43 used in this study was purchased from Indonesian Center for Rice Research, Subang, West Java. Ethanol, folin-ciocalteu's phenol reagent, gallic acid, and quercetin were from Merck (Darmstadt, Germany). $\mathrm{Na}_{2} \mathrm{CO}_{3}$ was obtained from Himedia (India)

\section{Rice preparation}

The paddy was dehulled using dehusking machine (Yanmar, Japan) to obtain brown rice and sorted to remove remaining paddy and impurities. Rice grains were then analyzed for length, width, and length to width ratio to determine its dimensions and shape. Brown rice sample was ground into fine powder by coffee grinder machine and sieved to 40 mesh. It was stored at $-20^{\circ} \mathrm{C}$ for further phenolic extraction.

\section{Characteristics of brown rice}

Analysis of moisture content was conducted duplicate by the official method of AOAC (2005). Measurement of length and width of rice grains by using vernier calliper (Mitutoyo, Japan) in ten rice grains for each replicate which randomly sampled. The length to width ratio as calculated duplicate by the eq:

$$
\text { Length to width ratio }(L / W)=\frac{\text { Rice average length }(\mathrm{mm})}{\text { Rice average width }(\mathrm{mm})}
$$

\section{Extraction of brown rice flour}

Brown rice flour $(5.0 \mathrm{~g})$ was extracted with $50.0 \mathrm{~mL}$ ethanol $80 \%(\mathrm{v} / \mathrm{v})$ in a sonicator (Biobase, China) for 10, 20, and 30 minutes at room temperature. The supernatant was filtered through a Toyo No. 3 filter paper and collected into a dark bottle. All extracts were stored at $-20{ }^{\circ} \mathrm{C}$ before analysis. The extraction was conducted duplicate.

\section{Determination of total phenolic content}

Brown rice extract $(200 \mu \mathrm{L})$ was mixed with $1.8 \mathrm{~mL}$ of $10 \times$ diluted Folin-Ciocalteu's phenol reagent. It was added by $1.8 \mathrm{~mL}$ of $\mathrm{Na}_{2} \mathrm{CO}_{3} 6 \%(\mathrm{w} / \mathrm{v})$ and incubated in a dark room for 90 minutes. The mixture was analyzed using a spectrophotometer (Thermo Scientific ${ }^{\text {TM }}$ GENESYSTM 150 UVVisible) at $725 \mathrm{~nm}$. Gallic acid was used as standard and expressed as mg gallic acid equivalent per 100 g dry sample (mg GAE/100g) (Munarko et al., 2020).

\section{Determination of total flavonoid content}

Total flavonoid content was analyzed according to (Pękal \& Pyrzynska, 2014) with slight modification. Rice extract ( $1 \mathrm{~mL}$ ) was mixed with $0.5 \mathrm{~mL} \mathrm{AlCl}_{3} 2 \%(\mathrm{w} / \mathrm{v})$ and $2.0 \mathrm{~mL}$ distilled water. After 20 minutes, the absorbance of the mixtures was read at $425 \mathrm{~nm}$ by using spectrophotometer (Thermo Scientific ${ }^{\text {TM }}$ GENESYSTM 150 UV-Visible). Quercetin standards of different concentrations were used for the calibration curve.

\section{Statistical analysis}

All sample was analyzed duplicates and presented as mean \pm SD. The analysis of the variance using SPSS 22, and calculating means and SD using microsoft excel. 


\section{Results and Discussion}

\section{Characteristics of brown rice var. inpari 43}

Table 1 showed the characteristics of brown rice grains var. Inpari 43. The moisture content of brown rice was $12.03 \pm 0.17 \%$, which is lower than $14 \%$, the safe moisture levels of processed rice (Verma \& Srivastav, 2017). Brown rice var. Inpari 43 is classified as medium and slender grain. Classification of length and shape of rice grains could be calculated by its length and ratio of length and width. Based on its length, brown rice could be classified into extra-long grain $\geq 7.50$, long grain 6.61-7.50, medium grain 5.51-6.60, and short-grain $\leq 5.50$. Meanwhile, grain shape was categorized based on its length/width ratio, i.e. slender $>3.0$, medium 2.1-3.0, bold 1.1-2.0, and round $\leq 1.0$ (Juliano, 1993; Murdifin et al., 2015).

Table 1. Moisture content and physical characteristics of brown rice grain var. Inpari 43

\begin{tabular}{lc}
\hline Parameters & Value (mean \pm SD) \\
\hline Moisture content $(\mathrm{g} / 100 \mathrm{~g})$ & $12.03 \pm 0.17$ \\
Length $(\mathrm{mm})$ & $6.58 \pm 0.22$ \\
Width $(\mathrm{mm})$ & $2.02 \pm 0.11$ \\
Length/Width ratio & $3.27 \pm 0.22$ \\
Grain length & Medium \\
Grain shape & Slender \\
\hline
\end{tabular}

\section{Total phenolic content of brown rive var. inpari 43 at different extraction time}

Phenolic content of brown rice flour var. Inpari 43 was significantly different at different sonication times $(p<0.05)$ (Figure 1). The highest phenolic content was observed in 30 min extraction time, followed by 20 minutes and 10 minutes. It means that the longer sonication time resulted in, the higher phenolic content extracted from rice flour.

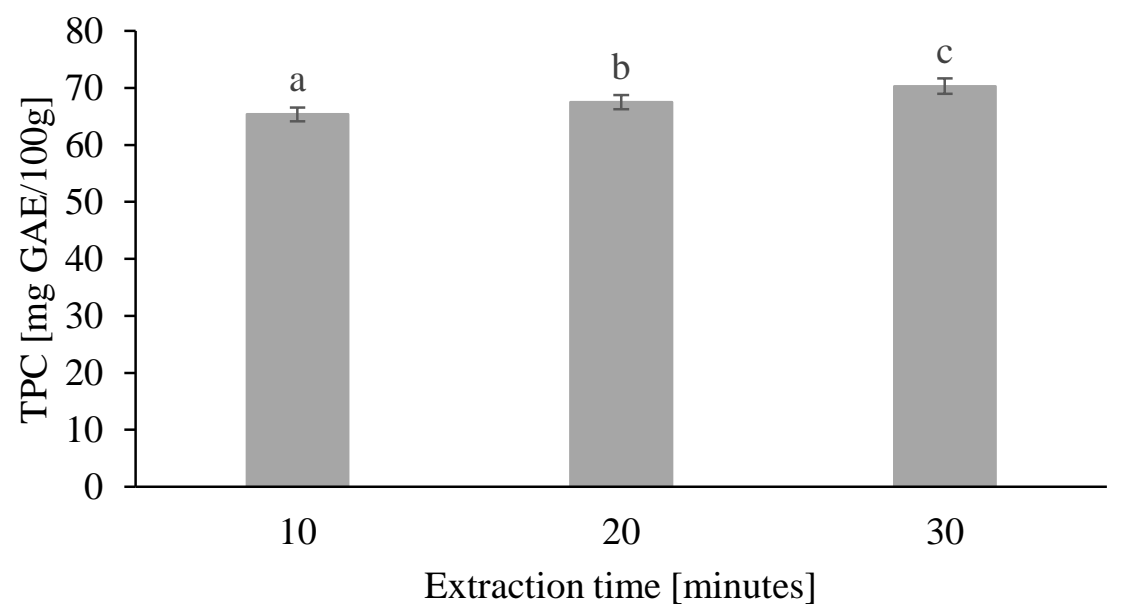

Figure 1. Total phenolic content (TPC) of brown rice flour var. Inpari 43 at different sonication time

\section{Total flavonoid content of brown rive var. inpari 43 at different extraction time}

Figure 2 showed total flavonoid content of brown rice var. Inpari 43 at different sonication time. The result exhibited that the extraction time significantly affected the yield of flavonoid content $(p<0.05)$. Sonication 30 minutes had the highest flavonoid content. In contrast, sonication 10 minutes accumulated the lowest amount of flavonoid. 


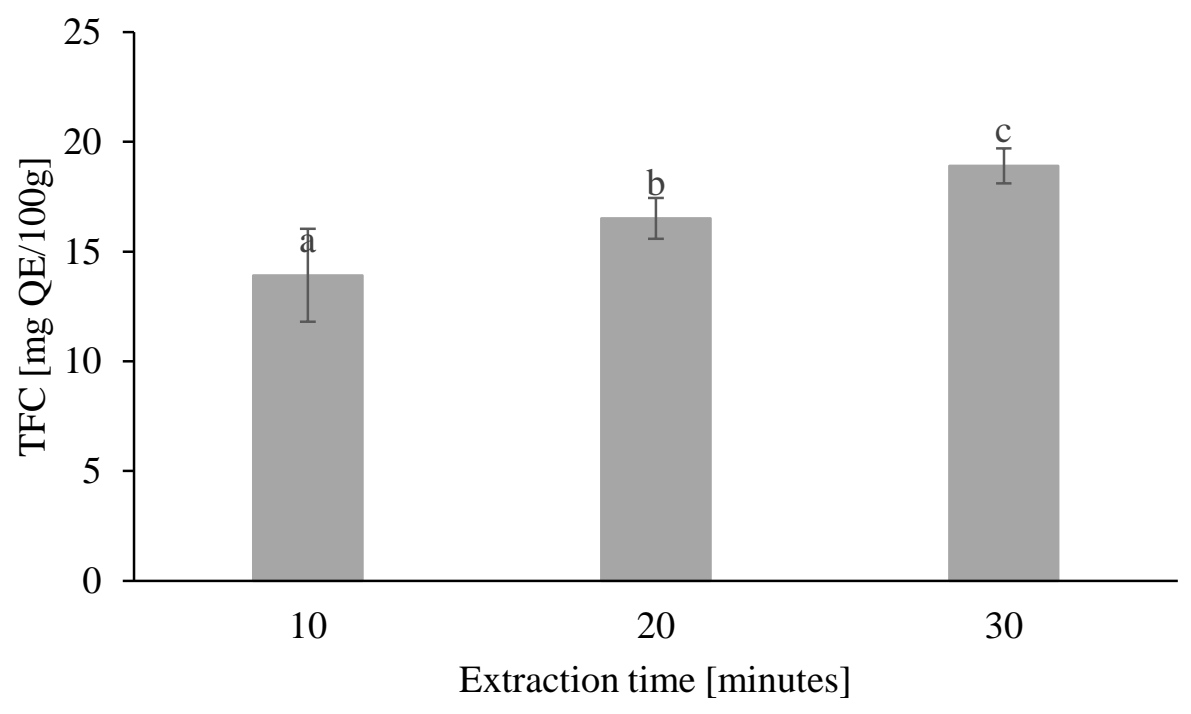

Figure 2. Total flavonoid content (TFC) of brown rice flour var. Inpari 43 at different sonication time

\section{Correlation between sonication time, total phenolic content, and total flavonoid content}

Pearson correlation analysis was used to evaluate the possible relationship among the variables. Based on the results, It could be seen that there is a strong positive correlation between sonication time and the accumulation of total phenolic content and total flavonoid content $(p<0.01)$. It indicated that the longer extraction time of brown rice flour resulted in the more phenolic acids and flavonoid was extracted.

Table 2. Pearson correlation between sonication time, total phenolic content, and total flavonoid content

\begin{tabular}{lrrr}
\hline Parameters & Time & $\begin{array}{r}\text { Total phenolic con- } \\
\text { tent }\end{array}$ & $\begin{array}{r}\text { Total flavonoid con- } \\
\text { tent }\end{array}$ \\
\hline Time & 1 & - & - \\
Total phenolic content & $0.865^{* *}$ & 1 & - \\
Total flavonoid con- & $0.845^{* *}$ & $0.739^{* *}$ & 1 \\
tent & & & \\
${ }^{* *}$ Correlation is significant at the 0.01 level (2-tailed) & &
\end{tabular}

\section{Conclusion}

Brown rice var. Inpari 43 is classified as medium and slender grain. Extraction of brown rice flour using sonicator could be used as an alternative method to extract phenolic and flavonoid content. Sonication for 30 minutes was able to accumulate the highest total phenolic and flavonoid content than that in 20 and 10 minutes. There was a strong positive correlation between sonication time and phenolic and flavonoid content.

\section{Acknowledgment}

The authors would like to acknowledge The Ministry of Research and Technology, and The Ministry of Education and Culture for supporting this research by Pendidikan Magister menuju Doktor untuk Sarjana Unggul (PMDSU) scholarship program for the first author. 


\section{References}

Juliano, B. O. (1993). Rice in human nutrition. Rome: Food and Agriculture Organization of the United Nations, P162.

Monton, C., \& Luprasong, C. (2019). Effect of temperature and duration time of maceration on nitrate content of Vernonia cinerea (L.) Less.: Circumscribed Central Composite Design and Method Validation. Int. J. Food. Sci, 2019, 1-8. https://doi.org/10.1155/2019/1281635

Munarko, H., Sitanggang, A. B., Kusnandar, F., \& Budijanto, S. (2020). Phytochemical, fatty acid and proximal composition of six selected Indonesian brown rice varieties. CyTA - J. of Food, 18(1), 336-343. https://doi.org/10.1080/19476337.2020.1754295

Murdifin, M., Pakki, E., Rahim, A., Syaiful, S. A., Evary, Y. M., \& Bahar, M. A. (2015). Physicochemical properties of indonesian pigmented rice (Oryza sativa Linn.) varieties from South Sulawesi. Asian J. of Plant Sci., 14(2), 59-65. https://doi.org/10.3923/ajps.2015.59.65

Pękal, A., \& Pyrzynska, K. (2014). Evaluation of aluminium complexation reaction for flavonoid content assay. Food Anal. Methods, 7(9), 1776-1782. https://doi.org/10.1007/s12161-014-9814-x

Qiu, Y., Liu, Q., \& Beta, T. (2010). Antioxidant properties of commercial wild rice and analysis of soluble and insoluble phenolic acids. Food Chem., 121(1), 140-147. https://doi.org/10.1016/i.foodchem.2009.12.021

Statistics Indonesia. (2019). The study of staple food consumption in Indonesia during year 2017. Available at https://www.bps.go.id/publication/2019/06/25/bbf8ec1716fb4583687996c3/kajian-konsumsi-bahan-pokoktahun-2017.html (in Indonesian language)

Verma, D. K., \& Srivastav, P. P. (2017). Proximate composition, mineral content and fatty acids analyses of aromatic and non-aromatic Indian rice. Rice Sci., 24(1), 21-31. https://doi.org/10.1016/j.rsci.2016.05.005 